a great aid towards the solution of the housing problem. Given this legislation and a proper organization to begin with, financial aid can produce better results.

In those Canadian provinces where ample town planning powers have been given by the legislatures there is a chance for treatment of these problems in a comprehensive and satisfactory way.

\title{
THE UNEARNED INCREMENT IN LACKAWANNA
}

BY HERBERT S. SWAN

New York

$\mathrm{B}$ EFORE the Lackawanna Steel Company brought its great plant and its thousands of employes to Lackwanna in 1899, the business establishments of the locality consisted of four groceries, one butcher shop, three saloons and two make-believe hotels. There were no factories. The population in the main followed the pursuit of farming and truck gardening for a livelihood.

Conditions were thoroughly rural. The town form of government satisfied all the requirements of the people. One constable safe-guarded the public peace and he found ample time, it is said, to engage in market gardening as well as in the real estate business when there was any real estate to be sold.

In 1890 the area within the present city contained a population estimated at 627 . In 1900 it is estimated that this had increased to 1,833 . In 1915 the state census showed that these farms, swamps and woodlands had become a busy city of $15,737.1$

Increased population means increased land values. Country roads are usually not converted into city streets, nor plowed fields into building lots without an accompanying unearned increment. The purpose of this paper will be to appraise as nearly as possible the amount of unearned ncrement accruing to land values from the coming of the steel plant to Lackawanna.

\section{THE AGRICULTURAL VALUE OF THE LAND}

Before the establishment of the steel plant there had been very little ictivity in the real estate market. As a general rule property was inrerited and not sold. The best land used for truck gardening purposes ;eems, however, to have possessed a value varying between $\$ 400$ and $\$ 500$ jer acre; the best land used for ordinary agricultural purposes, a value etween $\$ 150$ and $\$ 300$ per acre; and swamp land, a value not exceeding

1 This investigation was made at the request and with the support of Mr. Richard S, thilds on behalf of the Committee on New Industrial Towns in August, 1916. 
$\$ 100$ per acre. The value of some of the swamp and wood land did no exceed $\$ 50$ per acre. Although little property appears to have beer exchanged at these figures, they may be considered as representing the price at which land was held previous to its value being influenced by the construction of the breakwater, the railroad yards or the steel plant that is to say, about the year 1895. At that time the average acreag value of all the land in the city probably did not exceed $\$ 200$ per acre. On this latter basis the land within the present city limits was wortl only $\$ 770,000$. But this figure by no means represents what it cost th steel company to acquire the plant land in the absence of any power $t$, condemn.

\section{ACQUISITION OF THE PLANTS LAND}

The task of acquiring the property for the steel company was entruste to the Stony Point Land Company, of which Mr. J. J. Albright, a Buffal capitalist, was the head. This happened in the latter part of March 1899. Within a period of six weeks, this company had acquired titl not only to the greater part of the land required by the steel company bu to 500 or 600 acres in addition. Altogether about. 1,700 acres of lan were purchased at prices varying from $\$ 300$ to $\$ 4,000$ per acre. Th average was $\$ 980$ per acre.

The price obtained by each owner depended naturally to a large exten upon his native shrewdness in bargaining and the strategic position of $\mathrm{hj}$ property in relation to the other parcels in the scheme contemplated $b$, the company.

The first sellers, not suspecting that a big project was on foot, wer glad to dispose of their farms and swamps at a comparatively low figur These were the men who got $\$ 300$ per acre for their land. The las vendors, appreciating the vital importance of their land to the compan in rounding out and filling in its holdings, of course, made extortionat demands, and probably much to their own surprise, they got their pria These were the men who got from $\$ 2,000$ to $\$ 4,000$ per acre for their lanc

With the exception of two parcels, which were purchased by the ster company for housing purposes, the Stony Point Land Company retaine title to 650 acres not used for the plant. About 350 acres of this lan have been disposed of to different railways for yard purposes and to indu: trial establishments. The remaining 300 acres are still retained by th land company in large tracts and the general impression seems to $k$ that it doesn't care to sell this land.

The land bought in Lackawanna was 1,436 acres and the price paid w: approximately $\$ 1,407,000$.

The land bought by the company was the most valuable for factor

2 This figure represents the opinion of Messrs. C. H. McCullough, Jr., Robert A. Ree J. J. Redmond, N. C. Milks and Mansfield Lohr. 
purposes in the city. The remaining area of 2,414 acres could have been bought more cheaply, especially if it had been bought over a longer period of time. A tract of 150 acres needed to round out the company holdings would probably have cost $\$ 980$ an acre, the same price as that sold for the land acquired, or a total of $\$ 147,000$. The other area of 2,264 acres, if all bought, could probably have been purchased for two and a half times its agricultural value or at $\$ 500$ an acre. The price of this tract at $\$ 500$ per acre would have been $\$ 1,132,000$.

The aggregate amount that would have been required for the purchase of all the land within the city limits may therefore be estimated at $\$ 2,686,000$.

PRESENT VALUE OF THE LAND

The total assessed value of taxable real estate in Lackawanna, exclusive of special franchises, is $\$ 10,390,480$. This is the assessment on which the 1917 tax levy was made. Land is assessed at $\$ 4,678,360$; or $\$ 297$ per capita.

The city administration, including the mayor and the three assessors, steadfastly maintained that the assessment for 1917 was on the basis of 80 per cent of true value. The fear that the writer was engaged by the State Board of Tax Commissioners made the city administration very circumspect in discussing the relation of assessed and true value.

Mr. C. W. Ellis, Editor of the Journal, the leading city newspaper, stated that the assessments represented about 35 per cent of actual value. Mr. Mansfield Lohr, a real estate man, stated that they represented about 30 per cent; Mr. N. M. O'Mara, another real estate man, stated that the assessments varied from 25 per cent of true value in the case of vacant property to 40 per cent in the case of improved property. Mr. N. C. Milks said the assessments varied between 30 and 50 per cent of true value.

The county supervisors rated Lackawanna assessments at 30 per cent in 1916. The 1917 assessment is, however, about 50 per cent larger than that of 1916.

There are many instances where vacant as well as improved property is assessed at only a fifth or a sixth of its fair value.

Considering the fact that there are enormous areas of vacant land, the assessed value of the land, exclusive of improvements, does not on the average perhaps exceed one-third of its true value. The writer considers this ratio a very fair one. It errs rather on the side of conservatism than liberality.

Applying this ratio the present true value of the land within the city limits of Lackawanna is $\$ 14,035,000$; of the non-plant land $\$ 9,016,000$.

The gross increment in the non-plant land is the difference between its present value, $\$ 9,016,000$, and its value of $\$ 1,983,000$ in 1899 , or $\$ 7,033,000$. 


\section{COST OF LOCAL IMPROVEMENTS}

Benefits have been assessed quite generally in the case of local improvements.

Including the filling of swamp land, roads and sidewalks and the cost of local improvements assessed against benefited property, the property owners in Lackawanna have been put to a total expense of $\$ 500,000$ in preparing their property for urban use. But of this amount, they have, as yet, only paid some $\$ 245,000$.

The net increment in the non-plant land is therefore the difference between its gross increment of $\$ 7,033,000$ and the $\$ 245,000$ collected for local improvements or $\$ 6,788,000$.

\section{MUNICIPAL FINANCE AND TAXATION}

An analysis of the unearned increment in any particular city would not be complete without a word describing the conditions affecting municipal finance and taxation. Land and buildings were not assessed separately in Lackawanna until 1917. It is therefore impossible to show the annual tax burden to which land has been subject during the period in which this unearned increment developed.

The total cost of the government for the year 1915, considering the expense of both the municipal and the school corporations, was $\$ 290$,846.43 .

The tax rate for city and school purposes was $\$ 26.33$ per $\$ 1,000$ assessed value.

The city of Lackawanna has an outstanding debt for municipal and school purposes of $\$ 561,425$. All the bonds outstanding on account of sewers and one-half on account of pavements will be collected from owners of benefited property. Deducting these amounts, the net debt is $\$ 286,925$.

It is plain, therefore, that carrying charges on the land have not been a serious offset to the increment.

\section{SOCIAL CONDITIONS}

Had the unearned increment in land values been conserved for community purposes instead of dissipated among the land owners, Lackawanna would not be the drab place to live in it is to-day. The city possesses none of the amenities which make town life pleasant. It has no public library. It owns no parks, no playgrounds. ${ }^{3}$ The social conditions are such that most of the plant employes refuse to live in the city. About 60 per cent of the shop force and about 75 per cent of the office force, according to the president of the company, live in Buffalo. The difficulty the steel plant experiences in manning the works describes the desolate character of the community better than any words,-in a force

3 The only park in the city, one of 155 acres, belongs to the city of Buffalo. 
of about 7,000 men it had, when the writer was there, a labor turnover of 1,500 men a week!

The great common indulgence is drink, and drink in abundance. As nearly as the writer could ascertain there were about 140 saloons in Lackawanna. Nearly all of these were in the foreign quarter of the city west of the railroad yards. The population of this section, exclusive of that found in the company houses, is about 5,500 .

The saloon keeper seems to have been one of the first to realize the need for adequate housing facilities in the new town. He erected a number of two- and three-story barracks 30 to 35 feet in width and of ten more than 100 feet in length, the first floor being used as a saloon and the upper floors as lodgings. There are probably forty of these saloon lodging houses. The clientele of each bar is largely recruited, if not exclusively so, from its own lodgers. The ideal cherished by each saloon is apparently to shelter all its customers. Some of these saloons are said to accommodate as many as a hundred men, the same beds being used by both night and day men.

\section{SOCIALIZATION OF THE UNEARNED INCREMENT}

Various methods have been suggested and tried for the socialization of the unearned increment,--the more prominent among these being a heavy annual tax on land values, a $\operatorname{tax}$ on future increases in land values, ${ }^{4}$ Co-Partnership Housing ${ }^{5}$ and Municipal Land Ownership. That there is a right on the part of the community to enjoy and to benefit by the values which it itself creates does not at this late date seem susceptible of successful contradiction. But which of the above propositions is best designed to attain this end it is not the purpose of this paper to determine. Various social forces at work, however, make it increasingly plain that it is futile to expect even an approximately fair distribution of the economic rent through promoting individual home ownership In the first place, a majority of workingmen will never acquire a home, ${ }^{6}$ and on account of industrial conditions, it is a big question whether or not it is desirable to encourage them to own a home. In the second place, very little increment accrues, as a rule, to land used for housing the working classes after its original subdivision and sale. If not the bulk, at least a very large portion of the increment is in such instances reaped by the developer. And in the third place, individual home ownership, even if it were to become the universal rule in a community and thus secure a

- See Herbert S. Swan. The Unearned Increment Tax, National Monicipax REview, April, 1914.

"See Richard S. Childs, How Shall the Government Dispose of Its Industrial Housing, New Republic, March 30, 1918; also Herbert S. Swan, Co-Partnership Housing in England, Journal American Institute of Architects, May, 1918.

- See Herbert S. Swan, Home Ownership in New York City, Journal of American Institute of Architects, January, 1918. 
more or less haphazard distribution of the benefits resulting from the unearned increment in residential land values, would still not solve the problems resulting from the growth of land values in the business sections of the city.

To preserve the individual's mobility without at the same time obliging him to forego his right to share in the unearned increment he helps to create, that is the biggest part of the problem affecting the economic rent of land. Industrial towns, like Lackawanna, would probably find that such a solution to the land problem would do more to stabilize labor than any other policy they might adopt.

\title{
RECONSTRUCTION IN GREAT BRITAIN
}

\author{
BY THOMAS ADAMS \\ Ottawa, Canada
}

$I^{N}$

$\mathrm{N}$ that part of the British Empire from which I come, which has its boundaries common with yours for over 3,000 miles, we have very similar problems of reconstruction to those you have in the United States. Our problems more resemble yours than those of the Mother Country. In our different dominions our problems naturally vary with our conditions; only one thing never varies, namely, the freedom and independence of each national unit of the Empire. You will remember how Kipling described the spirit of combined independence and loyalty of Canada:-

A nation spoke to a nation,

A throne sent word to a throne:

"Daughter am I in my mother's house,

But mistress in my own.

The gates are mine to open,

As the gates are mine to close,

And I abide in my mother's house,"

Said our lady of the snows.

Canada has her own gates to open and to close and her own problems to work out in the light of her own experience. And it is only as nations and states, and lesser entities, "do the duty that is nearest to them", as Carlyle has put it, that national strength will be built up in such aggregations of territories and states as you and we have in our respective countries.

The war is past history. The boys have gone over, and they have done their duty. They have met the test. They have kept the faith. Many of them will not come back to reap the fruits of their sacrifice. We have been helping them in the struggle, but while they have had the 